\title{
Modulation of Trypanosoma cruzi-specific T-cell responses after chemotherapy for chronic Chagas disease
}

\author{
María Cecilia Albareda, Susana Adriana Laucella/ ${ }^{+}$ \\ Instituto Nacional de Parasitología Dr M Fatala Chaben, Buenos Aires, Argentina
}

\begin{abstract}
The aim of this review is to describe the contributions of the knowledge of T-cell responses to the understanding of the physiopathology and the responsiveness to etiological treatment during the chronic phase of Chagas disease. Thelper (Th)1 and interleukin (IL)-10 Trypanosoma cruzi-specific T-cells have been linked to the asymptomatic phase or to severe clinical forms of the disease, respectively or vice versa, depending on the T. cruzi antigen source, the patient's location and the performed immunological assays. Parasite-specific T-cell responses are modulated after benznidazole (BZ) treatment in chronically T. cruzi-infected subjects in association with a significant decrease in $\mathrm{T}$. cruzi-specific antibodies. Accumulating evidence has indicated that treatment efficacy during experimental infection with $\mathrm{T}$. cruzi results from the combined action of $B Z$ and the activation of appropriate immune responses in the host. However, strong support of this interaction in T. cruzi-infected humans remains lacking. Overall, the quality of T-cell responses might be a key factor in not only disease evolution, but also chemotherapy responsiveness. Immunological parameters are potential indicators of treatment response regardless of achievement of cure. Providing tools to monitor and provide early predictions of treatment success will allow the development of new therapeutic options.
\end{abstract}

Key words: T-cells - benznidazole - Chagas disease

Chagas disease, which is caused by the intracellular protozoan parasite Trypanosoma cruzi, affects approximately six-seven million people from southern California to South America and Western Europe (Bern et al. 2007, WHO 2015). In 20-30\% of infected individuals, this disease results in heart disease or megaoesophagus/megacolon, making Chagas disease the most common cause of infectious myocarditis worldwide (Feldman \& McNamara 2000). Early investigations suggested that Chagas disease had an autoimmune aetiology. However, an emerging consensus has indicated that the persistence of parasites might lead to immune exhaustion and altered host immunoregulation, which might be responsible for cumulative tissue damage in chronic Chagas disease (Tarleton 2003, Laucella et al. 2004, Albareda et al. 2006, Gutierrez et al. 2009).

Chemotherapy with nifurtimox or benznidazole (BZ) is recommended during both acute and early chronic phases of T. cruzi infection (de Andrade et al. 1996, Sosa-Estani et al. 1998). Several studies have also demonstrated the benefits of chemotherapy with BZ in adults with chronic T. cruzi infection (Viotti et al. 1994, Fabbro et al. 2007). Based on this evidence, experts advocate that treatment in adults without advanced heart disease should generally be offered (Bern et al. 2007).

In spite of these latter findings, treatment during the chronic phase of T. cruzi infection remains limited primarily because of the lack of early metrics of treat-

doi: 10.1590/0074-02760140386

+ Corresponding author: slaucella@yahoo.com

Received 17 October 2014

Accepted 20 March 2015 ment efficacy and the potential adverse effects of these therapeutics (Viotti et al. 2009).

Due to the low levels of parasitaemia in subjects with chronic T. cruzi infections, direct detection of T. cruzi or its products or constituents (e.g., DNA, proteins) (Cerisola et al. 1971, Zulantay et al. 2004) is inadequate for determining the effectiveness of treatment, but is useful primarily for indicating treatment failure (Duffy et al. 2013). The primary criterion of a positive response to treatment has been the complete loss of reactivity in serially performed conventional serological tests (i.e., ELISA, haemagglutination and immunofluorescence), as well as the lack of progression to more severe clinical symptoms of Chagas disease. However, the decrease in serological titres using current standard tests is extremely slow, requiring five-10 years to achieve conversion to negative serology in even a fraction of treated adult subjects (Viotti et al. 2006, Bertocchi et al. 2013). Disease progression also occurs over decades and does not occur in all infected individuals, irrespective of treatment (Viotti et al. 2005, Fabbro et al. 2007).

The low percentages of complete seronegative conversion after specific chemotherapy in subjects with long-term chronic T. cruzi infections have led to the most likely inaccurate idea that treatment during the chronic phase is useless. Here, we review the contributions of the knowledge of T-cell responses to the understanding of how treatment works with the aim of providing new tools to monitor and predict treatment success during the chronic phase of T. cruzi infection.

Function and phenotype of T-cells responsive to T. cruzi antigens

The original goals of the studies from our group were to better understand T-cell responses to T. cruzi in chronically infected subjects and to correlate these responses with cardiac disease severity. The frequency, phenotype 
and function of T-cells responsive to T. cruzi antigens were measured in adults (30-70 years of age) and children (5-16 years of age) with chronic Chagas disease living in areas nonendemic for T. cruzi infection in Argentina. The primary findings included an overall low level of detectable T. cruzi-specific T-cells and the predominance of single cytokine [interferon (IFN)- $\gamma$ only]-producing T-cells in the circulation of adult subjects with long-term T. cruzi infections (Alvarez et al. 2008) (Table I). Conversely, children presumed to have shorter-term infections showed parasite-specific T-cell responses that were more robust and more highly functional (Albareda et al. 2013) (Table I). The simultaneous secretion of IFN- $\gamma$ and interleukin (IL)-2 was prevalent among T. cruzi-infected children (Albareda et al. 2013), while monofunctional responses were higher in T. cruzi-infected adults compared with infected children (Albareda et al. 2006, Alvarez et al. 2008) (Table I). Polyfunctional T-cell responses are important because these cells are optimised for effector function, including higher IFN- $\gamma$ secretion on a per-cell basis, more efficient killing by IFN- $\gamma$ and tumour necrosis factor (TNF)- $\alpha$ compared with either cytokine alone and IL-2-mediated expansion of T-cells in an autocrine or paracrine manner, which could enhance T-cell memory function (Seder et al. 2008, Virgin et al. 2009).

Other authors have also reported that children in the early phase of chronic $T$. cruzi infection exhibit IFN- $\gamma$ and TNF- $\alpha$-secreting CD4 ${ }^{+}$T-cells in response to T. cruzi antigens (Samudio et al. 1998, Sathler-Avelar et al. 2006); however, these responses were associated with IL-10 production by $\mathrm{CD}^{+}{ }^{+} \mathrm{T}$-cells (Sathler-Avelar et al. 2006). Therefore, the maintenance of functional T-cells is proposed to control parasite replication without the induction of tissue damage and these responses appear to be impaired with the length of the infection. IL-10 might counteract T-helper (Th)1 responses, which, if sustained overtime, might be deleterious for the host (Dutra \& Gollobb 2008).

Because phenotypic defects in T-cells might arise along with functional ability loss, the phenotypic profile of T. cruzi-specific T-cells has also been evaluated in chronic Chagas disease patients. The pool of parasite-specific IFN$\gamma$-producing $\mathrm{CD}^{+} \mathrm{T}$-cells is primarily composed of $\mathrm{CD} 122$ (the common beta chain of IL-2 and IL-15 receptors) low and chemokine receptor 7 low T-cells, while some of these cells express CD127 (the homeostatic IL-7 receptor), which is consistent with effector memory T-cells (TEMs) (Figure). TEMs that are characteristic of persistent infections have low proliferative capacity and primarily migrate to peripheral tissues; however, in contrast to effector T-cells, TEMs may persist in the host. Furthermore, a fraction of T. cruzi-specific T-cells exhibit low expression levels of killer cell lectin-like receptor (KLRG)1, CD57 and leukocyte immunoglobulin-like receptor (LIR)-1 (Argüello et al. 2012), while T-cells expressing the costimulation molecules CD27 and CD28 are enriched (Figure) (Albareda et al. 2006, 2009). Considering that KLRG1 and CD57 expression increases with the rounds of antigen stimulation and that CD27 and CD28 expression is down-regulated (Appay et al. 2008) while LIR-1 expression is up-regulated during T-cell differentiation (Antrobus et al. 2005), these findings indicate that naïve $\mathrm{CD} 4^{+} \mathrm{T}$-cells may also be re-

\section{TABLE I}

Trypanosoma cruzi-specific T-cell responses in children and adults with Chagas disease living in nonendemic areas of Argentina measured by interferon (IFN)- $\gamma$ and interleukin (IL)-2 ELISPOT

Positive responders/total T. cruziinfected subjects evaluated

Positive ELISPOT

responses to $T$. cruzi lysate $\mathrm{n} / \mathrm{n}(\%)$

\begin{tabular}{lcc}
\hline IFN- $\gamma+$ IL-2 & $10 / 17(58.8)^{a, b}$ & $4 / 22(18)$ \\
IFN- $\gamma$-only & $3 / 17(17.6)^{c}$ & $11 / 22(50)$ \\
IL-2-only & $0 / 17(0)$ & $0 / 22(0)$
\end{tabular}

$a$ : Fisher exact test $\mathrm{p}=0.0181$ vs. percentage of IFN- $\gamma$-only responders in $T$. cruzi-infected children; $b$ : $\mathrm{p}<0.02$ vs. percentage of IFN- $\gamma+$ IL-2 in adults; $c$ : $p<0.05$ vs. percentage of IFN- $\gamma$-only in adults.

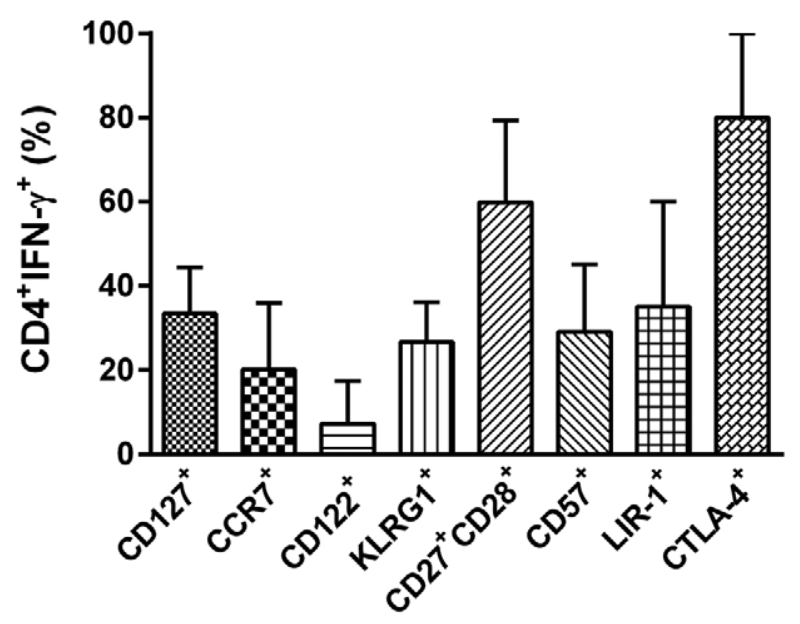

Phenotypic characterization of Trypanosma cruzi-specif CD4 $4^{+}$T-cells in chronically infected subjects. Peripheral blood mononuclear cells from eight patients were stimulated with $15 \mathrm{ug} / \mathrm{mL}$ of $T$. cruzi lysate from the Brazil strain for 16-20 h. CD4 interferon (IFN)- $\gamma^{+}$T-cells were selected and analysed for the expression of CD127, chemokine receptor (CCR)7, CD122, killer cell lectin-like receptor (KLRG)1, CD27, CD28, CD57, immunoglobulin-like receptor (LIR)-1 and cytotoxic T lymphocyte antigen (CTLA)-4 by flow cytometry. Means values \pm standard deviation are shown.

cruited for T-cell responses in chronically infected subjects. Long-term infection with $T$. cruzi also results in the up-regulation of cytotoxic T lymphocyte antigen-4 (Figure) (Argüello et al. 2012) likely as part of a homeostatic process to control tissue damage, although this up-regulation might damper T-cell responses. The above-described findings are compatible with immune exhaustion, which has described for other chronic parasitic and viral infections (Gigley et al. 2012, Rodrigues et al. 2014). 


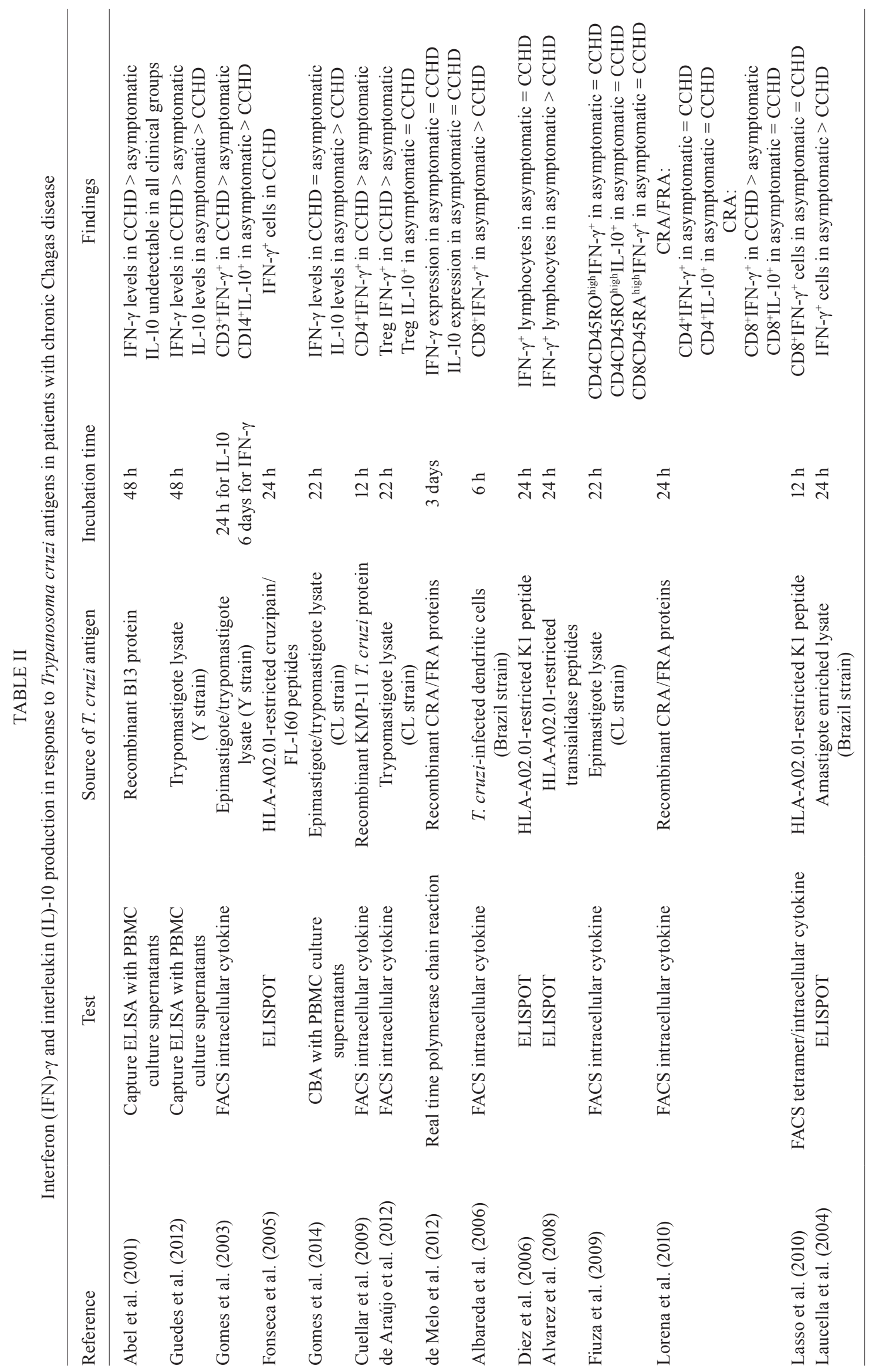




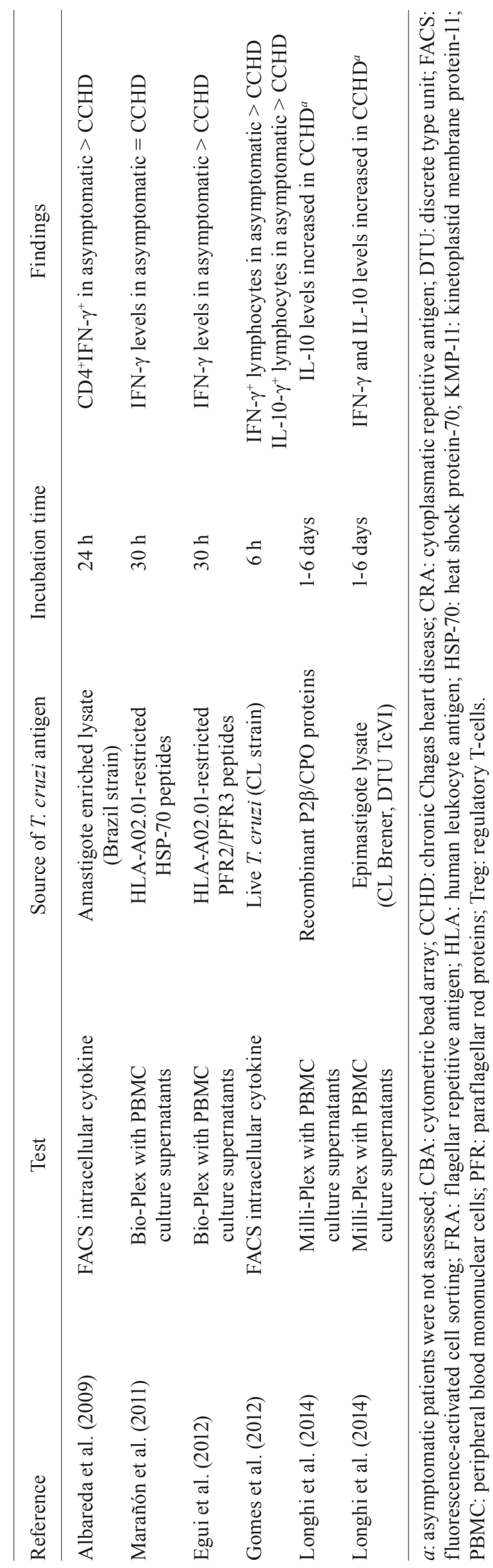

Notably, dissimilar findings have been reported regarding the association of IFN- $\gamma$ and IL-10 production in response to T. cruzi antigens with disease severity during the chronic phase of infection in adult subjects (Table II). In contrast to our findings, increased IFN- $\gamma$ production after stimulating peripheral blood mononuclear cells (PBMCs) with T. cruzi antigens was observed in patients with severe cardiomyopathy compared to seropositive subjects with no signs of cardiac disease (Abel et al. 2001, Guedes et al. 2012), whereas IL-10 production was either detected in asymptomatic patients (Guedes et al. 2012, Gomes et al. 2014) or undetectable (Abel et al. 2001) (Table II). Similarly, patients with severe cardiomyopathy had higher frequencies of $\mathrm{CD}^{+}$or $\mathrm{CD}^{+}{ }^{+} \mathrm{T}$-cells, including $\mathrm{CD}^{+}{ }^{+} \mathrm{Foxp} 3^{+} \mathrm{CD} 25 \mathrm{hi} \mathrm{T}$-cells with the ability to secrete IFN- $\gamma$ in response to T. cruzi antigens (Gomes et al. 2003, Cuellar et al. 2009, de Araújo et al. 2012), whereas IL-10 -secreting cells were found primarily during the asymptomatic phase (Gomes et al. 2003) or detected in all clinical groups (de Araújo et al. 2012). In a recent study focused on Chagas disease patients with severe cardiomyopathy, increased levels of IFN- $\gamma$ and IL-10 specific for T. cruzi antigens have been reported (Longhi et al. 2014).

In contrast to these findings, comparable frequencies of $\mathrm{CD} 4^{+} \mathrm{T}$-cells producing IFN- $\gamma$ and IL-10 were reported in patients with no signs of cardiac disease and those with severe cardiomyopathy (Fiuza et al. 2009). Stimulating PBMCs with cytoplasmatic repetitive antigen (Lafaille 1989, Kriegger 1992) induced IFN- $\gamma$, IL-4 and TNF- $\alpha$ production by $\mathrm{CD}^{+} \mathrm{T}$-cells in patients with or without cardiac disease (Lorena et al. 2010). Additionally, only subjects in the indeterminate phase of Chagas disease presented higher frequencies of CD4 ${ }^{+} \mathrm{IL}-10^{+} \mathrm{T}$-cells compared with uninfected controls; however, these levels did not differ from those found in patients with severe cardiomyopathy. In contrast, when flagellar repetitive antigen (Lafaille et al. 1989, Kriegger et al. 1992) was used as the antigen source, $\mathrm{CD} 4^{+} \mathrm{IL} 10^{+} \mathrm{T}$-cells were detected in both patients in the indeterminate phase of the disease and those presenting cardiomyopathy, while the frequencies of $\mathrm{CD} 4^{+} \mathrm{IFN}-\gamma^{+} \mathrm{T}$-cells remained unaltered compared with uninfected controls (Lorena et al. 2010).

In another study, de Melo et al. (2012) reported that most patients in the indeterminate phase of the infection displayed increased IFN- $\gamma$ gene expression after stimulation with $T$. cruzi antigens, while the majority of patients with cardiomyopathy had high levels of IL-10.

The use of soluble parasite antigens vs. in vitro infection might also lead to different results. In fact, Gomes et al. (2012) recently demonstrated that the short-term in vitro culture of whole blood samples with live T. cruzi parasites led to increased IFN- $\gamma^{+}$and IL- $10^{+}$lymphocytes in subjects with no sign of cardiac disease compared with those with severe cardiomyopathy, in contrast to previous reports from the same group showing increased levels of IFN- $\gamma$ upon stimulation with an epimastigote/ trypomastigote lysate (Gomes et al. 2003).

Little information is available regarding $\mathrm{CD} 8^{+} \mathrm{T}$-cell responses in subjects with chronic T. cruzi infection primarily because the complexity of the $T$. cruzi genome has made it difficult to identify individual targets of $\mathrm{CD} 8^{+}$ 
T-cell responses in T. cruzi-infected subjects. In an attempt to identify and quantify T-cell responses to defined T. cruzi epitopes, we tested human leukocyte antigen (HLA)-A2.1-restricted CD8 ${ }^{+}$T-cell responses (HLA-A2.1 is one of the most common class I alleles in this population) to several trans-sialidase-derived epitopes using a combination of HLA-A2 tetramers, ELISPOT analysis and intracellular cytokine staining assays (Martin et al. 2006, Alvarez et al. 2008) (Table II). The percentage of responders strongly correlated with disease severity, with $60 \%$ of individuals in the indeterminate phase, but only $22 \%$ of the subjects with cardiomyopathy responding to trans-sialidase peptides (Alvarez et al. 2008). When CD $8^{+}$ T-cell responses were measured using T. cruzi-infected autologous dendritic cells, we observed that subjects with less severe forms of the cardiac disease were more likely to mount $T$. cruzi-specific IFN- $\gamma$ responses than subjects with severe cardiomyopathy (Albareda et al. 2006) (Table II). HLA-A201-restricted epitopes derived from kinetoplastid membrane protein (KMP)-11 (Diez et al. 2006, Lasso et al. 2010), heat shock protein (HSP)-70 (Marañón et al. 2011), FL-160 (Fonseca et al. 2005) or cruzipain (Fonseca et al. 2005) have also been reported as targets of IFN- $\gamma$ responses by $\mathrm{CD} 8^{+} \mathrm{T}$-cells in chronically $T$. cruziinfected subjects (Table II). While no differences in the magnitude of T-cell responses specific for KMP-11 and HSP-70-derived peptides according to the clinical stage of the disease were found, IFN- $\gamma$ secretion in response to HLA-A2.01-restricted paraflagellar rod proteins (PRP)-2 and PRP-3-derived peptides was higher in patients in the indeterminate phase of the infection compared with patients with cardiac disease (Egui et al. 2012) (Table II). Concerning the phenotype of $\mathrm{CD}^{+} \mathrm{T}$-cells specific for $T$. cruzi antigens, $\mathrm{CD} 8^{+} \mathrm{IFN}-\gamma^{+} \mathrm{T}$-cells predominantly showed an effector memory phenotype were enriched in $\mathrm{CD} 27^{+} \mathrm{CD} 28^{+}$ cells in response to T. cruzi (Albareda et al. 2006).

As a whole, Th1 and IL-10-producing T-cells can be detected in the different clinical groups of the chronic infection, with a degree of variation according to the $T$. cruzi antigen source, the patient's location and immunological assays. The quality of T-cell responses might determine the pattern of the cellular response and the severity of the disease in $T$. cruzi infection.

\section{Modulation of $T$. cruzi-specific T-cell responses following chemotherapy}

To gain a clearer understanding of the relationship between parasite persistence and T. cruzi-specific T-cell maintenance during chronic Chagas disease, we examined the changes in the frequency of T. cruzi-specific T-cells in adult subjects with chronic T. cruzi infection following BZ treatment. We showed that the levels of IFN- $\gamma$-producing T-cells in response to a T. cruzi lysate preparation significantly decreased over 12 months following BZ treatment and that IFN- $\gamma$-secreting T-cells fell below the level of detection by 36 months post-treatment (Laucella et al. 2009), along with a significant drop in antibody levels specific for a set of recombinant proteins (Laucella et al. 2009, Viotti et al. 2011) as determined by multiplex serological assays (Cooley et al. 2008), in 15 of 32 (47\%) patients. This latter assay appeared to be more sensitive than conventional serological tests in detecting changes in antibody levels following BZ treatment. Surprisingly, a proportion of BZ-treated, but not untreated, subjects exhibited an initial increase in IFN- $\gamma$ responses before the decrease at 12 months post-treatment (Laucella et al. 2009). We hypothesise that this transient rise in IFN- $\gamma$-secreting T-cells might be triggered by a release of parasite antigens due to BZ-induced parasite death and might enhance the parasiticidal effect of the drug. The most straightforward interpretation of these results is that $\mathrm{BZ}$ treatment decreases the parasite load, thus diminishing the antigen that is required to maintain the T. cruzi-specific effector T-cells.

Other studies have measured T-cells responsive to $T$. cruzi antigens after BZ treatment in subjects with chronic T. cruzi infection. Of note, these studies focused on the comparison of subjects treated with BZ with those untreated or uninfected; however, these comparisons were not pre-treatment/post-treatment comparisons. A shift towards a type two-modulated profile with a higher level of IL-10 production was found in the $\mathrm{CD}^{+} \mathrm{T}$-cell compartment, whereas high IFN- $\gamma$ expression was observed in $\mathrm{CD} 8^{+} \mathrm{T}$-cells of $T$. cruzi-infected children after one year of BZ treatment (Sathler-Avelar et al. 2008). Likewise, the treatment of chronically $T$. cruzi-infected adult subjects with no signs of cardiac disease led to increased levels of TNF- $\alpha^{+} \mathrm{CD} 8^{+}$and IFN- $\gamma^{+} \mathrm{CD} 8^{+} \mathrm{T}$-cells (Sathler-Avelar et al. 2012) with unchanged frequencies of CD4 ${ }^{+} \mathrm{IL}-17^{+} \mathrm{T}$-cells (Guedes et al. 2012) in response to T. cruzi antigens. Subjects with chronic T. cruzi infection who were treated with BZ 14-30 years earlier and achieved serological cure showed higher levels of IFN- $\gamma$ production specific for $T$. cruzi compared with patients who had not been cured (Bahia-Oliveira et al. 2000).

In a mouse model of acute and chronic T. cruzi infections, BZ treatment resulted in the emergence of $T$. cruzi-specific central memory T-cells (Bustamante et al. 2008). A reduction in the total numbers of activated and TEMs after the treatment of infected mice has also been shown (Fernández et al. 2009). A positive treatment outcome was demonstrated by the observation that treated animals were protected against re-infection (Olivieri et al. 2002). Altogether, changes in T. cruzi-specific T-cell responses can be potential early indicators of treatment response, even in cases in which cure is not achieved. Long-term monitoring of T-cell responses following chemotherapy in relation to the serological evolution by conventional serology, which is currently the only gold standard of treatment efficacy in Chagas disease, will allow the usefulness of immunological parameters as surrogate markers of treatment efficacy to be validated.

\section{Immunocompetence as a factor of treatment efficacy in $T$. cruzi infection}

The immunological status of the host might also be a determining factor of treatment success. In this respect, a relationship between treatment success and the immune status pre-therapy has been demonstrated in human immunodeficiency virus positive subjects under highly active antiretroviral therapy (Marchetti et al. 2012). 
That the immune response can be a key factor in the efficacy of treatment against $T$. cruzi has been documented in experimental acute $T$. cruzi infections; however, strong support of this correlation in T. cruziinfected humans remains lacking. In a murine model of $T$. cruzi infection, treating IFN- $\gamma$, IL-12, protein, 55-TNF receptor and inducible nitric oxide synthase knockout mice with BZ reduced the cure rates to $42 \%$, $35 \%$ and $28 \%$, respectively, compared with wild-type animals (Romanha et al. 2002). The absence of $\mathrm{CD}^{+} \mathrm{T}$ cells dramatically affected the efficacy of BZ treatment, whereas parasitaemia and cure rates were less affected by the absence of $\mathrm{CD}^{+} \mathrm{T}$-cells and $\mathrm{B}$ cells (Ferraz et al. 2009). The administration of blocking antibodies for IL-12 or IFN- $\gamma$ concomitant with a suboptimal dose of BZ enhanced parasitaemia and accelerated mortality, while treatment efficacy did not change in mice treated with optimal doses of BZ (Michailowsky et al. 1998). Simultaneous treatment with a suboptimal dose of BZ and recombinant IL-12 enhanced the efficacy of drug treatment as measured by parasitaemia levels and mouse survival (Michailowsky et al. 1998).

Likewise, BZ treatment during experimental T. cruzi infection in mice enhanced phagocytosis, parasite destruction and cytokine release by macrophages (Murta et al. 1999) and led to a partial reversion of spleen and lymph node enlargement observed in $T$. cruzi-infected untreated mice (Olivieri et al. 2006). These findings support the notion that drug treatment responsiveness results from the combined action of the drug and the activation of appropriate immune responses in the host.

\section{Future directions}

A throughout knowledge of how drug treatment works might provide guidance regarding how to most effectively treat and monitor therapy outcomes in chronically $T$. cruzi-infected individuals. Providing tools to not only monitor, but also provide early predictions of treatment success or failure will allow the development of new therapeutic options. The notion that improving host immune responses to $T$. cruzi could enhance treatment efficacy remains unexplored in $T$. cruzi-infected subjects and deserves future research.

\section{REFERENCES}

Abel LC, Rizzo LV, Ianni B, Albuquerque F, Bacal F, Carrara D, Bocchi EA, Teixeira HC, Mady C, Kalil J, Cunha-Neto E 2001. Chronic Chagas disease cardiomyopathy patients display an increased IFN-gamma response to Trypanosoma cruzi infection. J Autoimmun 17: 99-107.

Albareda MC, de Rissio AM, Tomas G, Serjan A, Alvarez MG, Viotti R, Fichera LE, Esteva MI, Potente D, Armenti A, Tarleton RL, Laucella SA 2013. Polyfunctional T-cell responses in children in early stages of chronic Trypanosoma cruzi infection contrast with monofunctional responses of long-term infected adults. PLoS Negl Trop Dis 7: e2575.

Albareda MC, Laucella SA, Alvarez MG, Armenti AH, Bertochi G, Tarleton RL, Postan M 2006. Trypanosoma cruzi modulates the profile of memory $\mathrm{CD} 8^{+} \mathrm{T}$ cells in chronic Chagas disease patients. Int Immunol 18: 465-471.

Albareda MC, Olivera GC, Laucella SA, Alvarez MG, Fernandez ER, Lococo B, Viotti R, Tarleton RL, Postan M 2009. Chronic human infection with Trypanosoma cruzi drives $\mathrm{CD} 4^{+} \mathrm{T}$-cells to immune senescence. J Immunol 183: 4103-4108.

Alvarez MG, Postan M, Weatherly DB, Albareda MC, Sidney J, Sette A, Olivera C, Armenti AH, Tarleton RL, Laucella SA 2008. HLA class ccI-T-cell epitopes from trans-sialidase proteins reveal functionally distinct subsets of $\mathrm{CD}^{+} \mathrm{T}$ cells in chronic Chagas disease. PLoS Negl Trop Dis 2: e288.

Antrobus RD, Khan N, Hislop AD, Montamat-Sicotte D, Garner LI, Rickinson AB, Moss PA, Willcox BE 2005. Virus-specific cytotoxic $\mathrm{T}$ lymphocytes differentially express cell-surface leukocyte immunoglobulin-like receptor-1, an inhibitory receptor for class I major histocompatibility complex molecules. J Infect Dis 191: 1842-1853.

Appay V, van Lier RA, Sallusto F, Roederer M 2008. Phenotype and function of human $\mathrm{T}$ lymphocyte subsets: consensus and issues. Cytometry A 73: 975-983.

Argüello RJ, Albareda MC, Alvarez MG, Bertocchi G, Armenti AH, Vigliano C, Meckert PC, Tarleton RL, Laucella SA 2012. Inhibitory receptors are expressed by Trypanosoma cruzi-specific effector T-cells and in hearts of subjects with chronic Chagas disease. PLOS ONE 7: e35966.

Bahia-Oliveira LM, Gomes JA, Cançado JR, Ferrari TC, Lemos EM, Luz ZM, Moreira MC, Gazzinelli G, Correa-Oliveira R 2000. Immunological and clinical evaluation of chagasic patients subjected to chemotherapy during the acute phase of Trypanosoma cruzi infection 14-30 years ago. J Infect Dis 182: 634-638.

Bern C, Montgomery SP, Herwaldt BL, Rassi Jr A, Marin-Neto JA, Dantas RO, Maguire JH, Acquatella H, Morillo C, Kirchhoff LV, Gilman RH, Reyes PA, Salvatella R, Moore AC 2007. Evaluation and treatment of Chagas disease in the United States: a systematic review. JAMA 298: 2171-2181.

Bertocchi GL, Vigliano CA, Lococo BG, Petti MA, Viotti RJ 2013. Clinical characteristics and outcome of 107 adult patients with chronic Chagas disease and parasitological cure criteria. Trans $R$ Soc Trop Med Hyg 107: 372-376.

Bustamante JM, Bixby LM, Tarleton RL 2008. Drug-induced cure drives conversion to a stable and protective $\mathrm{CD} 8^{+} \mathrm{T}$ central memory response in chronic Chagas disease. Nat Med 14: 542-550.

Cerisola JA, Alvarez M, Bock M, Wegner D 1971. A comparison of a new antigen from amastigotes of Trypanosoma cruzi and an antigen from epimastigotes for the diagnosis of Chagas disease by the indirect immunofluorescence test. Rev Inst Med Trop Sao Paulo 13: 162-166.

Cooley G, Etheridge RD, Boehlke C, Bundy B, Weatherly DB, Minning T, Haney M, Postan M, Laucella S, Tarleton RL 2008. High throughput selection of effective serodiagnostics for Trypanosoma cruzi infection. PLoS Negl Trop Dis 2: e316.

Cuellar A, Rojas F, Bolaños N, Diez H, Thomas MDC, Rosas F, Velasco V, López MC, González JM, Puerta C 2009. Natural CD4 (+) T-cell responses against Trypanosoma cruzi KMP-11 protein in chronic chagasic patients. Immunol Cell Biol 87: 149-153.

de Andrade AL, Zicker F, de Oliveira RM, Silva SA, Luquetti A, Travassos LR, Almeida IC, de Andrade SS, de Andrade JG, Martelli CM 1996. Randomised trial of efficacy of benznidazole in treatment of early Trypanosoma cruzi infection. Lancet 348: 1407-1413.

de Araújo FF, Corrêa-Oliveira R, Rocha MO, Chaves AT, Fiuza JA, Fares RC, Ferreira KS, Nunes MC, Keesen TS, Damasio MP, Teixeira-Carvalho A, Gomes JA 2012. Foxp3 ${ }^{+} \mathrm{CD} 25$ (high) CD4+ regulatory T-cells from indeterminate patients with Chagas disease can suppress the effector cells and cytokines and reveal altered correlations with disease severity. Immunobiology 217: 768-777.

de Melo AS, de Lorena VM, Braz SCM, Docena C, Gomes YM 2012. IL-10 and IFN- $\gamma$ gene expression in chronic Chagas disease patients after in vitro stimulation with recombinant antigens of Trypanosoma cruzi. Cytokine 58: 207-212. 
Diez H, López MC, Thomas MDC, Guzmán F, Rosas F, Velazco V, González JM, Puerta C 2006. Evaluation of IFN-gamma production by $\mathrm{CD} 8 \mathrm{~T}$ lymphocytes in response to the K1 peptide from KMP-11 protein in patients infected with Trypanosoma cruzi. Parasite Immunol 28: 101-105.

Duffy T, Cura CI, Ramirez JC, Abate T, Cayo NM, Parrado R, Bello ZD, Velazquez E, Muñoz-Calderon A, Juiz NA, Basile J, Garcia L, Riarte A, Nasser JR, Ocampo SB, Yadon ZE, Torrico F, de Noya BA, Ribeiro I, Schijman AG 2013. Analytical performance of a multiplex real-time PCR assay using TaqMan probes for quantification of Trypanosoma cruzi satellite DNA in blood samples. PLoS Negl Trop Dis 7: e2000.

Dutra WO, Gollobb KJ 2008. Current concepts in immunoregulation and pathology of human Chagas disease. Curr Opin Infect Dis 21: $287-292$

Egui A, Thomas MC, Morell M, Marañón C, Carrilero B, Segovia M, Puerta CJ, Pinazo MJ, Rosas F, Gascón J, López MC 2012. Trypanosoma cruzi paraflagellar rod proteins 2 and 3 contain immunodominant CD8 (+) T-cell epitopes that are recognized by cytotoxic T-cells from Chagas disease patients. Mol Immunol 52: 289-298.

Fabbro DL, Streiger ML, Arias ED, Bizai ML, del Barco M, Amicone NA 2007. Trypanocide treatment among adults with chronic Chagas disease living in Santa Fe city (Argentina) over a mean follow-up of 21 years: parasitological, serological and clinical evolution. Rev Soc Bras Med Trop 40: 1-10.

Feldman AM, McNamara D 2000. Myocarditis. N Engl J Med 343: 1388-1398.

Fernández MC, Cappa SMG, Solana ME 2009. Trypanosoma cruzi: immunological predictors of benznidazole efficacy during experimental infection. Exp Parasitol 124: 172-180.

Ferraz ML, Gazzinelli RT, Alves RO, Urbina JA, Romanha AJ 2009. Absence of $\mathrm{CD}^{+} \mathrm{T}$ lymphocytes, $\mathrm{CD} 8^{+} \mathrm{T}$ lymphocytes or B lymphocytes has different effects on the efficacy of posaconazole and benznidazole in treatment of experimental acute Trypanosoma cruzi infection. Antimicrob Agents Chemother 53: 174-179.

Fiuza JA, Fujiwara RT, Gomes JA, Rocha MO, Chaves AT, de Araújo FF, Fares RC, Teixeira-Carvalho A, Martins-Filho OA, Cançado GG, Correa-Oliveira R 2009. Profile of central and effector memory Tcells in the progression of chronic human Chagas disease. PLoS Negl Trop Dis 3: e512.

Fonseca SG, Moins-Teisserenc H, Clave E, Ianni B, Nunes VL, Mady C, Iwai LK, Sette A, Sidney J, Marin ML, Goldberg AC, Guilherme L, Charron D, Toubert A, Kalil J, Cunha-Neto E 2005. Identification of multiple HLA-A*0201-restricted cruzipain and FL-160 $\mathrm{CD}^{+}$epitopes recognized by T-cells from chronically Trypanosoma cruzi-infected patients. Microbes Infect 7: 688-697.

Gigley JP, Bhadra R, Moretto MM, Khan IA 2012. T-cell exhaustion in protozoan disease. Trends Parasitol 28: 377-384.

Gomes JA, Bahia-Oliveira LM, Rocha MO, Martins-Filho OA, Gazzinelli G, Correa-Oliveira R 2003. Evidence that development of severe cardiomyopathy in human Chagas disease is due to a Th1-specific immune response. Infect Immun 71: 1185-1193.

Gomes JA, Campi-Azevedo AC, Teixeira-Carvalho A, Silveira-Lemos D, Vitelli-Avelar D, Sathler-Avelar R, Peruhype-Magalhães V, Silvestre KF, Batista MA, Schachnik NC, Correa-Oliveira R, Eloi-Santos S, Martins-Filho OA 2012. Impaired phagocytic capacity driven by downregulation of major phagocytosis-related cell surface molecules elicits an overall modulatory cytokine profile in neutrophils and monocytes from the indeterminate clinical form of Chagas disease. Immunobiology 217: 1005-1016.

Gomes JA, Molica AM, Keesen TS, Morato MJ, de Araújo FF, Fares RC, Fiuza JA, Chaves AT, Pinheiro V, Nunes MC, Correa-Ol- iveira R, Rocha MOC 2014. Inflammatory mediators from monocytes down-regulate cellular proliferation and enhance cytokines production in patients with polar clinical forms of Chagas disease. Hum Immunol 75: 20-28.

Guedes PM, Gutierrez FR, Silva GK, Dellalibera-Joviliano R, Rodrigues GJ, Bendhack LM, Rassi Jr A, Rassi A, Schmidt A, Maciel BC, Marin Neto JA, Silva JS 2012. Deficient regulatory T-cell activity and low frequency of IL-17-producing T cells correlate with the extent of cardiomyopathy in human Chagas disease. PLoS Negl Trop Dis 6: e1630.

Gutierrez FR, Guedes PM, Gazzinelli RT, Silva JS 2009. The role of parasite persistence in pathogenesis of Chagas heart disease. Parasite Immunol 31: 673-685.

Krieger MA, Almeida E, Oelemann W, Lafaille JJ, Pereira JB, Krieger H, Carvalho MR, Goldenberg S 1992. Use of recombinant antigens for the accurate immunodiagnosis of Chagas disease. Am J Trop Med Hyg 46: 427-434.

Lafaille JJ, Linss J, Krieger MA, Souto-Padrón T, de Souza W, Goldenberg S 1989. Structure and expression of two Trypanosoma cruzi genes encoding antigenic proteins bearing repetitive epitopes. Mol Biochem Parasitol 35: 127-136.

Lasso P, Mesa D, Cuéllar A, Guzmán F, Bolaños N, Rosas F, Velasco V, Thomas MC, Lopez MC, Gonzalez JM, Puerta CJ 2010. Frequency of specific $\mathrm{CD} 8^{+} \mathrm{T}$ cells for a promiscuous epitope derived from Trypanosoma cruzi KMP-11 protein in chagasic patients. Parasite Immunol 32: 494-502.

Laucella SA, Mazliah DP, Bertocchi G, Alvarez MG, Cooley G, Viotti R, Albareda MC, Lococo B, Postan M, Armenti A, Tarleton RL 2009. Changes in Trypanosoma cruzi-specific immune responses after treatment: surrogate markers of treatment efficacy. Clin Infect Dis 49: 1675-1684

Laucella SA, Postan M, Martin D, Fralish BH, Albareda MC, Alvarez MG, Lococo B, Barbieri G, Viotti RJ, Tarleton RL 2004. Frequency of interferon-gamma-producing T-cells specific for Trypanosoma cruzi inversely correlates with disease severity in chronic human Chagas disease. J Infect Dis 189: 909-918.

Longhi SA, Atienza A, Prados GP, Buying A, Balouz V, Buscaglia CA, Santos R, Tasso LM, Bonato R, Chiale P, Pinilla C, Judkowski VA, Gómez KA 2014. Cytokine production but lack of proliferation in peripheral blood mononuclear cells from chronic Chagas disease cardiomyopathy patients in response to T. cruzi ribosomal P proteins. PLoS Negl Trop Dis 8: e2906.

Lorena VM, Lorena IM, Braz SC, Melo AS, Melo MF, Melo MG, Silva ED, Ferreira AG, Morais CN, Costa VM, Correa-Oliveira R, Gomes YM 2010. Cytokine levels in serious cardiopathy of Chagas disease after in vitro stimulation with recombinant antigens from Trypanosoma cruzi. Scand J Immunol 72: 529-539.

Marañón C, Egui A, Carrilero B, Thomas MC, Pinazo MJ, Gascón J, Segovia M, López MC 2011. Identification of HLA-A* 02:01-restricted CTL epitopes in Trypanosoma cruzi heat shock protein-70 recognized by Chagas disease patients. Microbes Infect 13: 1025-1032.

Marchetti G, Merlini E, Sinigaglia E, Iannotti N, Bai F, Savoldi A, Tincati C, Carpani G, Bini T, Monforte AA 2012. Immune reconstitution in HIV+ subjects on lopinavir/ritonavir-based HAART according to the severity of pre-therapy CD4+. Curr HIV Res 10: 597-605.

Martin DL, Weatherly DB, Laucella SA, Cabinian MA, Crim MT, Sullivan S, Heiges M, Craven SH, Rosenberg CS, Collins MH, Sette A, Postan M, Tarleton RL 2006. CD8 ${ }^{+}$T-cell responses to Trypanosoma cruzi are highly focused on strain-variant transsialidase epitopes. PLoS Pathog 2: e77.

Michailowsky V, Murta SM, Carvalho-Oliveira L, Pereira ME, Ferreira LR, Brener Z, Romanha AJ, Gazzinelli RT 1998. Interleukin-12 
enhances in vivo parasiticidal effect of benznidazole during acute experimental infection with a naturally drug-resistant strain of Trypanosoma cruzi. Antimicrob Agents Chemother 42: 2549-2556.

Murta SM, Ropert C, Alves RO, Gazzinelli RT, Romanha AJ 1999. Invivo treatment with benznidazole enhances phagocytosis, parasite destruction and cytokine release by macrophages during infection with a drug-susceptible but not with a derived drug-resistant Trypansoma cruzi population. Parasite Immunol 21: 535-544.

Olivieri BP, Cotta-de-Almeida V, Araújo-Jorge T 2002. Benznidazole treatment following acute Trypanosoma cruzi infection triggers $\mathrm{CD} 8^{+} \mathrm{T}$-cell expansion and promotes resistance to reinfection. Antimicrob Agents Chemother 46: 3790-3796.

Olivieri BP, de Souza AP, Cotta-de-Almeida V, de Castro SL, Araújo-Jorge T 2006. Trypanosoma cruzi: alteration in the lymphoid compartments following interruption of infection by early acute benznidazole therapy in mice. Exp Parasitol 114: 228-234.

Rodrigues V, Cordeiro-da-Silva A, Laforge M, Ouaissi A, Akharid K, Silvestre R, Estaquier J 2014. Impairment of T-cell function in parasitic infections. PLoS Negl Trop Dis 8: e2567.

Romanha AJ, Alves RO, Murta SM, Silva JS, Ropert C, Gazzinelli RT 2002. Experimental chemotherapy against Trypanosoma cruzi infection: essential role of endogenous interferon-gamma in mediating parasitologic cure. J Infect Dis 186: 823-828.

Samudio M, Montenegro-James S, Cabral M, Martinez J, de Arias AR, James MA 1998. Cytokine responses in Trypanosoma cruziinfected children in Paraguay. Am J Trop Med Hyg 58: 119-121.

Sathler-Avelar R, Vitelli-Avelar DM, Elói-Santos SM, Gontijo ED, Teixeira-Carvalho A, Martins-Filho OA 2012. Blood leukocytes from benznidazole-treated indeterminate Chagas disease patients display an overall type-1-modulated cytokine profile upon short-term in vitro stimulation with Trypanosoma cruzi antigens. BMC Infect Dis 12: 123.

Sathler-Avelar R, Vitelli-Avelar DM, Massara RL, Borges JD, Lana M, Teixeira-Carvalho A, Dias JC, Elói-Santos SM, Martins-Filho OA 2006. Benznidazole treatment during early-indeterminate Chagas disease shifted the cytokine expression by innate and adaptive immunity cells toward a type 1-modulated immune profile. Scand J Immunol 64: 554-563.

Sathler-Avelar R, Vitelli-Avelar DM, Massara RL, de Lana M, Dias JCP, Teixeira-Carvalho A, Elói-Santos SM, Martins-Filho OA 2008. Etiological treatment during early chronic indeterminate
Chagas disease incites an activated status on innate and adaptive immunity associated with a type 1-modulated cytokine pattern. Microbes Infect 10: 103-113.

Seder RA, Darrah PA, Roederer M 2008. T-cell quality in memory and protection: implications for vaccine design. Nat Rev Immunol 8: $247-258$.

Sosa-Estani S, Segura EL, Ruiz AM, Velazquez E, Porcel BM, Yampotis C 1998. Efficacy of chemotherapy with benznidazole in children in the indeterminate phase of Chagas disease. Am J Trop Med Hyg 59: 526-529.

Tarleton RL 2003. Chagas disease: a role for autoimmunity? Trends Parasitol 19: 447-451.

Viotti R, Vigliano C, Alvarez MG, Lococo B, Petti M, Bertocchi G, Armenti A, de Rissio AM, Cooley G, Tarleton R, Laucella S 2011. Impact of aetiological treatment on conventional and multiplex serology in chronic Chagas disease. PLoS Negl Trop Dis 5: e1314.

Viotti R, Vigliano C, Armenti H, Segura E 1994. Treatment of chronic Chagas disease with benznidazole: clinical and serologic evolution of patients with long-term follow-up. Am Heart J 127: 151-162.

Viotti R, Vigliano C, Lococo B, Alvarez MG, Petti M, Bertocchi G, Armenti A 2009. Side effects of benznidazole as treatment in chronic Chagas disease: fears and realities. Expert Rev Anti Infect Ther 7: 157-163.

Viotti R, Vigliano C, Lococo B, Bertocchi G, Petti M, Alvarez MG, Postan M, Armenti A 2006. Long-term cardiac outcomes of treating chronic Chagas disease with benznidazole versus no treatment: a nonrandomized trial. Ann Intern Med 144: 724-734.

Viotti R, Vigliano C, Lococo B, Petti M, Bertocchi G, Alvarez MG, Armenti A 2005. Clinical predictors of chronic chagasic myocarditis progression. Rev Esp Cardiol 58: 1037-1044.

Virgin HW, Wherry EJ, Ahmed R 2009. Redefining chronic viral infection. Cell 138: 30-50.

WHO - World Health Organization 2015. Chagas disease (American trypanosomiasis). Available from: who.int/mediacentre/factsheets/fs340/en/.

Zulantay I, Honores P, Solari A, Apt W, Ortiz S, Osuna A, Rojas A, López B, Sánchez G 2004. Use of polymerase chain reaction (PCR) and hybridization assays to detect Trypanosoma cruzi in chronic chagasic patients treated with itraconazole or allopurinol. Diagn Microbiol Infect Dis 48: 253-257. 